\title{
Grain-size features of two large eruptions from Cotopaxi volcano (Ecuador) and implications for the calculation of the total grain-size distribution
}

\author{
Kae Tsunematsu ${ }^{1,2} \cdot$ Costanza Bonadonna $^{1}$
}

Received: 6 January 2014 / Accepted: 10 June 2015 / Published online: 25 June 2015

(C) Springer-Verlag Berlin Heidelberg 2015

\begin{abstract}
Studies of grain-size distributions of explosive volcanic eruptions provide important insights into fragmentation mechanisms and eruptive conditions and are crucial to the modeling of tephra dispersal. As a result of sedimentation processes and plume dynamics, grain-size features vary significantly both in the downwind and crosswind directions and are difficult to characterize. We have analyzed grain-size features in the downwind and crosswind directions of the two largest eruptions of the last 2000 years of Cotopaxi volcano activity (Ecuador). Crosswind grain-size variations are similar for both eruptions (i.e., layers 3 and 5), while at any given downwind distance from vent, the layer 3 deposit is coarser than the layer 5 one. This suggests that layers 3 and 5 were characterized by similar plume height but that layer 3 was advected by a stronger wind. In addition, both deposits are coarsest along the dispersal axis and become richer in ash in the crosswind direction showing a Gaussian decreasing rate. Deposit thickness also shows a Gaussian crosswind decay, but layer 3 is significantly thicker at all points than is layer 5 due to the former's larger erupted mass. Based on both quantitative analysis of field data and on numerical simulations, we show that tephra deposits associated with large explosive eruptions (i.e., plume height of $30 \mathrm{~km}$ ) should be sampled out to at least $200 \mathrm{~km}$ from the vent (depending on wind speed and
\end{abstract}

Editorial responsibility: M.L. Coombs

Kae Tsunematsu

kae.tsunematsu@gmail.com

1 Section of Earth and Environmental Sciences, University of Geneva, 13, Rue des Maraîchers, 1205 Genève, Switzerland

2 Mount Fuji Research Institute, Yamanashi Prefectural Government, 5597-1 Aza-Kenmarubi Kamiyoshida,

Fujiyoshida-shi, Yamanashi 403-0005, Japan tropopause height) in order to derive complete grain-size distributions that are not depleted in fines. Eruptions occurring in a strong wind field at high latitudes (e.g., Iceland) require lesser representative-sampling distances because of the lower tropopause heights.

Keywords Tephra $\cdot$ Total grain-size distribution $\cdot$ Plinian eruptions $\cdot$ Voronoi tessellation $\cdot$ Mdphi

\section{Introduction}

Knowing the source characteristics of a volcanic eruption is necessary to understand the associated dynamics and hazards. In particular, erupted volume, plume height, mass eruption rate, duration, and total grain-size distribution (TGSD) are all fundamental physical parameters that need to be determined in order to characterize an explosive eruption (e.g., Pyle 1989; Fierstein and Nathanson 1992; Carey and Sparks 1986; Mastin et al. 2009; Wilson and Walker 1987). Of these, the TGSD is one of the most difficult to derive (e.g., Bonadonna and Houghton 2005; Walker 1980; Murrow et al. 1980; Carey and Sigurdsson 1982; Parfitt 1998), but it is necessary to investigate fragmentation mechanisms (e.g., Kaminski and Jaupart 1998) and to forecast the spreading and sedimentation of associated volcanic clouds, which has obvious hazard implications (Bonadonna and Costa 2013; Folch 2012 and references therein). Tephra deposits are typically sampled at various locations for thickness and grain size, and then individual sample grain-size distributions are integrated together to derive the TGSD (e.g., Walker 1971, 1980, 1981a, b, c; Murrow et al. 1980; Sparks et al. 1981; Carey and Sigurdsson 1982; Parfitt 1998). Bonadonna and Houghton (2005) have shown how the Voronoi tessellation represents a robust statistical tool to describe non-uniform distributions. Nonetheless, all 
techniques are strongly dependent on the deposit preservation and sampling strategy. Two granulometric statistical parameters, $\mathrm{Md}_{\Phi}$ and $\sigma_{\Phi}$, are used to assess eruptive style and sedimentation processes (e.g., Inman 1952; Walker 1971; Bursik et al. 1992; Koyaguchi and Ohno 2001a, b).

In this paper, we present the results of grain-size analysis carried out on the tephra deposits associated with two large plinian eruptions of Cotopaxi volcano (layers 3 and 5; Barberi et al. 1995; Biass and Bonadonna 2011). The last 2000 years of Cotopaxi activity produced 22 tephra deposits with mostly uniform composition (basaltic andesite to andesite) but different textural features (Barberi et al. 1995). Six of these tephra deposits are characterized by black scoriae, six by white pumices, and the remainder are characterized by yellow to gray lapilli. Column heights vary between 28 and $39 \mathrm{~km}$ a.s.l., with the highest columns being associated with the gray and black

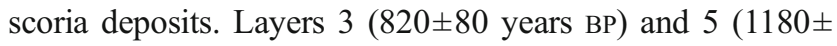
80 years BP) are the best-preserved tephra deposits of this period and are associated with white pumices and black scoriae, respectively (Fig. 1). In fact, even though they are both andesitic (62 and 58 wt.\% $\mathrm{SiO}_{2}$ respectively; Barberi et al. 1995), they show completely different clast microtextures (Costantini 2010). Biass and Bonadonna (2011) have

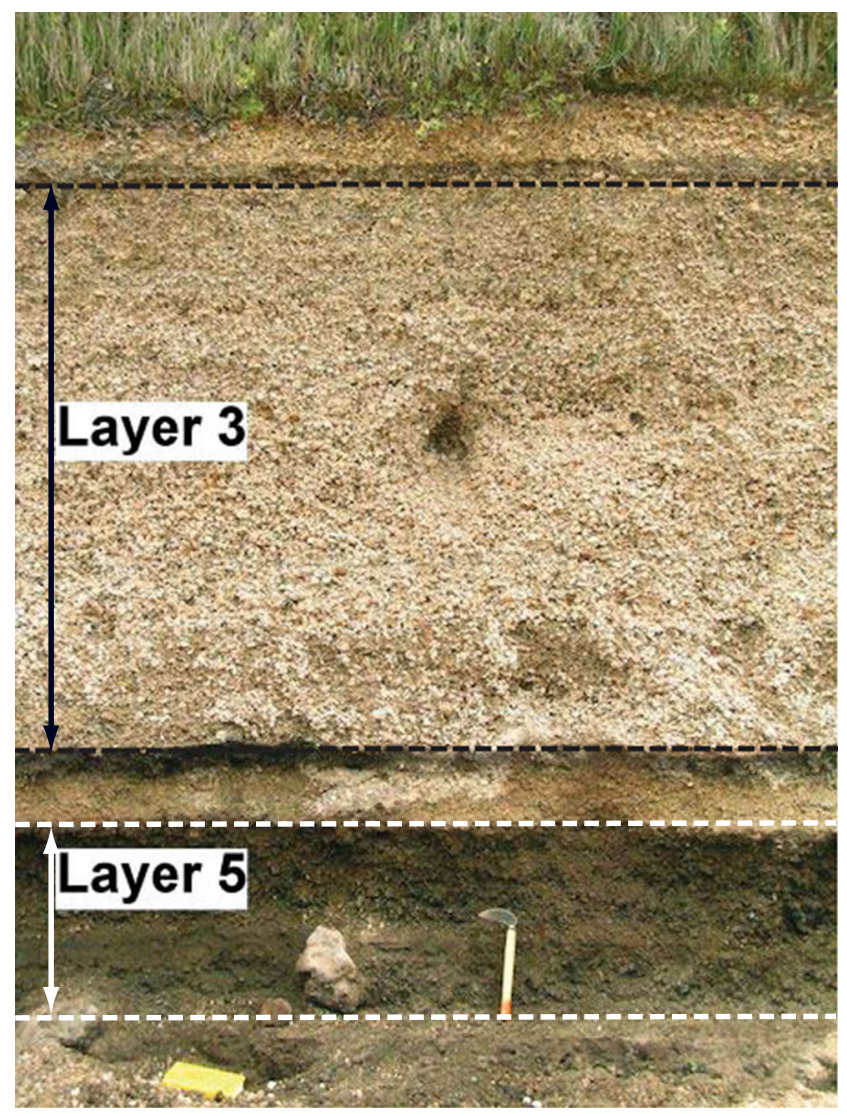

Fig. 1 Outcrop located $9.7 \mathrm{~km}$ from vent (CP001 in Fig. 2b) showing both layers 3 and 5 of Cotopaxi volcano (named after Barberi et al 1995). Thickness of layer 3 is $179.0 \mathrm{~cm}$, and thickness of layer 5 is $27.5 \mathrm{~cm}$ characterized most physical parameters of these two eruptions (Table 1). Here, we investigate the grain-size features of the associated deposits, compare their dispersal with tephra deposits from other explosive eruptions, and draw important conclusions on the general meaning of TGSD typically derived from tephra deposits.

\section{Methods}

Samples of layers 3 and 5 were dry-sieved down to $63 \mu \mathrm{m}$ (4 $\Phi)$ at the University of Geneva, and the fine-ash fraction $(<63 \mu \mathrm{m})$ was analyzed using the CILAS 1180 laser diffraction analyzer equipped with the wet dispersion mode, which provides a measurement range from 0.04 to $2500 \mu \mathrm{m}$ (http:// www.cilas.com/granulometrie.html). Volume fractions were converted into weight fraction assuming constant particle density, which is appropriate for particles $<63 \mu \mathrm{m}$ (Eychenne et al. 2012). The two techniques were validated based on size overlapping between 3 and $4 \Phi$ carried out for selected samples. Both isopach and $\mathrm{Md}_{\Phi}$ maps were hand drawn based on thickness and grain-size data (Figs. 2 and 3).

Dedicated Lagrangian simulations were carried out to explore particle dispersal and investigate the completeness of TGSD. Particles representing each grain-size category $\Phi$ were released from the vent and transported within a static velocity field associated with the vertical plume (Woods 1988; Sparks 1986), with the horizontal cloud spreading as a gravity current (Bonadonna and Phillips 2003). Wind transport was described based on the vertical profile of wind speed, which is almost zero at the ground and linearly increases with altitude to a maximum at the tropopause then linearly decreases again. Particle sedimentation was described based on the assumption of spherical particle shapes and with fallout regimes as described in Bonadonna and Phillips (2003). Particle trajectories were tracked at constant time steps. Critical input parameters (initial velocity, plume radius at vent, gas mass fraction at vent, and plume temperature at vent) were stochastically sampled from suitable ranges (Table 2). Simulations were performed only for particles $\leq 3 \Phi(\geq 125 \mu \mathrm{m})$ because particles $>3 \Phi$ typically fall as aggregates at higher settling speeds (e.g., Brown et al. 2012).

\section{Results}

The isopach map of layer 3 is more elongated than the isopach map of layer 5 due to stronger wind advection (Fig. 2). This direction of maximum elongation is considered as the downwind axis, while the perpendicular directions are set as crosswind sections. The $\mathrm{Md}_{\Phi}$ isograde map of layer 3 also shows slightly more pronounced elongation than that of layer 5 (Fig. 3). 
Table 1 Physical parameters of Cotopaxi layers 3 and 5 eruptions (from Biass and Bonadonna 2011)

\begin{tabular}{|c|c|c|c|}
\hline Parameters & Layer 3 & Layer 5 & Methods \\
\hline Plume height above vent (km) & $23 \pm 1$ & $26 \pm 1$ & $\begin{array}{l}\text { From the model of Carey and Sparks (1986) using the geometric mean } \\
\text { of the } 5 \text { largest clasts }\end{array}$ \\
\hline Erupted volume $\left(\mathrm{km}^{3}\right)$ & 2.4 & 0.5 & Inversion technique with TEPHRA2 (Connor and Connor 2006) \\
\hline Erupted mass $(\mathrm{kg})$ & $1.7 \times 10^{12}$ & $0.6 \times 10^{12}$ & $\begin{array}{l}\text { Converted from volume based on deposit density ( } 700 \text { and } 950 \mathrm{~kg} / \mathrm{m}^{3} \\
\text { for layers } 3 \text { and } 5 \text {, respectively) }\end{array}$ \\
\hline Mass eruption rate $(\mathrm{kg} / \mathrm{s})$ & $4.0 \pm 0.9 \times 10^{7}$ & $5.9 \pm 0.7 \times 10^{7}$ & From plume height based on the model of Wilson and Walker (1987) \\
\hline Eruption duration (min) & $570 \pm 195$ & $134 \pm 25$ & Ratio between erupted mass (from inversion) and mass eruption rate \\
\hline Wind speed at tropopause $(\mathrm{m} / \mathrm{s})$ & 2 & 21 & From the application of the model of Carey and Sparks (1986) \\
\hline Volcanic explosive index & 5 & 4 & Based on erupted volume; Newhall and Self (1982) \\
\hline
\end{tabular}

Fig. 2 a Isopach map of layer 3 (cm). Pink triangles indicate the samples along the crosswind section 1 (CW1; $15.7 \mathrm{~km}$ from the vent). Green triangles indicate the samples along the crosswind section 2 (CW2; $18.0 \mathrm{~km}$ from the vent). b Isopach map for layer 5 (cm). Pink triangles indicate the samples along the crosswind section 1 (CW1; $0 \mathrm{~km}$ from the vent). Green triangles indicate the samples along the crosswind section 2 (CW2; $7.3 \mathrm{~km}$ from the vent). Violet triangles indicate the samples along the crosswind section 3 (CW3; $14.7 \mathrm{~km}$ from the vent). In both maps, yellow triangles indicate the samples used for the calculation along the downwind axis, black circles indicate other samples considered in the calculation of the TGSD, and empty circles indicate outcrops used to compile the isopach maps but that were not considered in the calculation of total grain size. Dashed red lines indicate the line of zero-mass loading (used for the Voronoi tessellation). Zero line 1 is the original zero line defined based on our field work. Zero lines 2 and 3 are 5 and $10 \mathrm{~km}$ outside zero line 1. Yellow lines indicate downwind and crosswind sections considered in this study (i.e., DW, CW1, CW2, CW3)
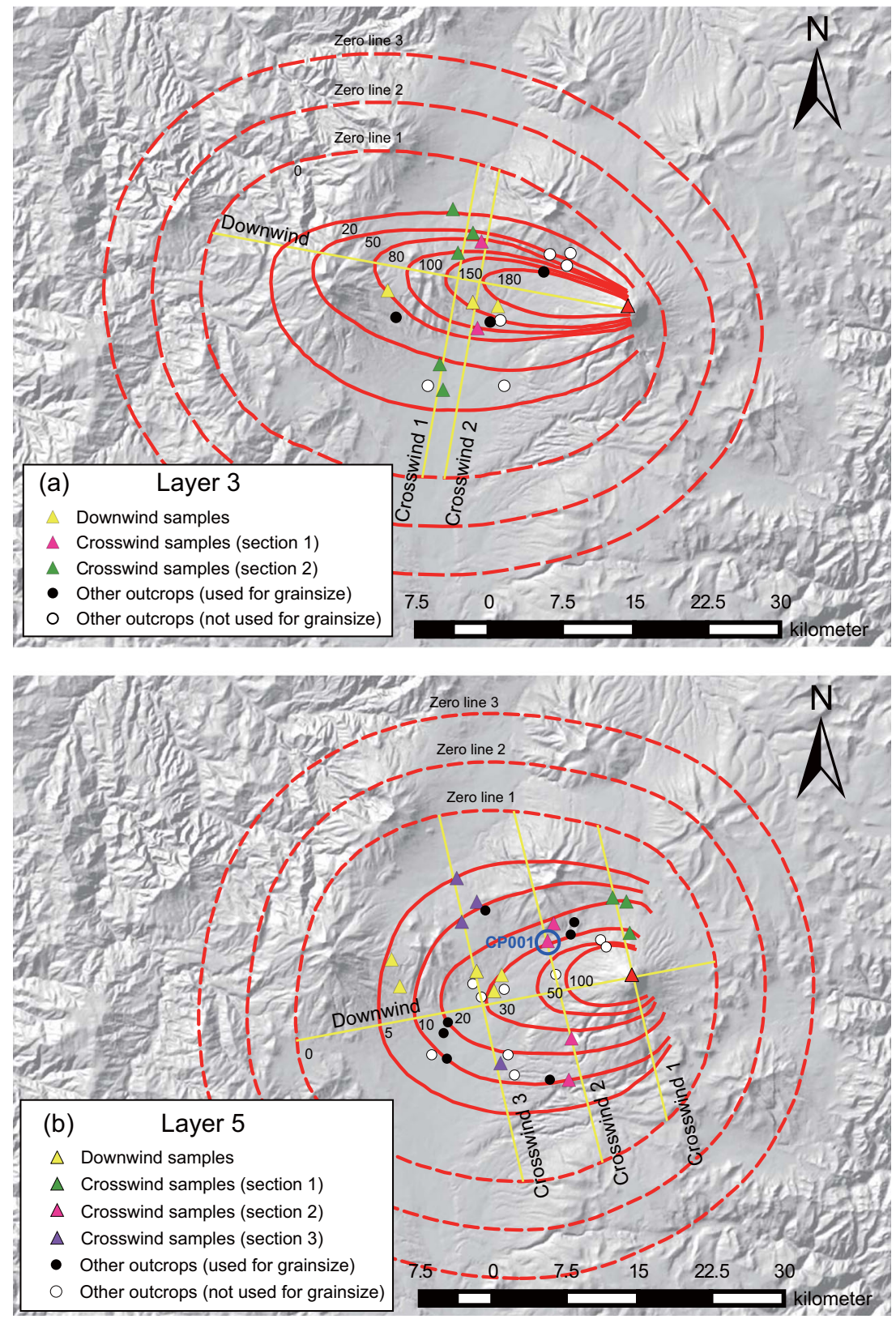
Fig. 3 IsoMd $_{\Phi}$ map ( $\Phi$ unit: $\Phi=$ $-\log _{2} d$, where $d$ is the particle diameter in $\mathrm{mm}$ ) for a layers 3 and b 5. Colors of points show the range of $\mathrm{Md}_{\Phi}$ value (see legend)
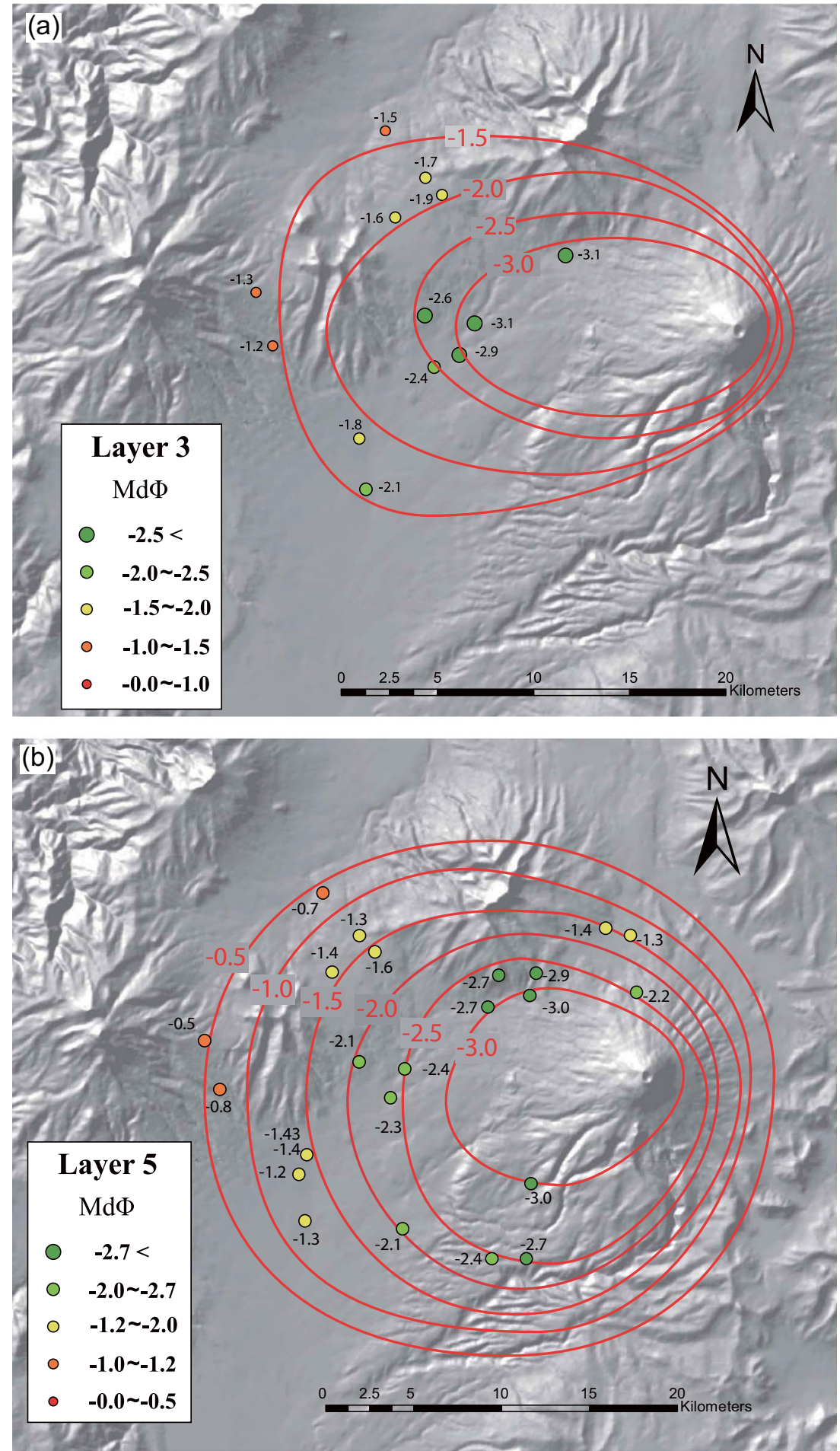

\section{Trend of grain-size distribution along the dispersal axis}

Values of $\mathrm{Md}_{\Phi}$ increase with distance from the vent at a similar rate for layers 3 and 5 (i.e., similar slope in Fig. 4a). However, layer 3 is always coarser than layer 5 at any given distance from the vent. The amount of ash (particles $<2 \mathrm{~mm}, \geq 0$ $\Phi)$ also increases with distance from the vent for both layers 3 and 5 (Fig. 4b). In contrast, sorting does not show any particular trend with distance from the vent and varies between 1.3 and 1.7 (Fig. 4c).

The comparison of two crosswind sections with a similar distance from the vent (CW1 for layer 3, $15.7 \mathrm{~km}$ from vent, and CW3 for layer 5, $14.7 \mathrm{~km}$ from the vent) shows a very similar crosswind grain-size variation for the two units 
Table 2 Range of input parameters for deriving plume velocity profile used in the Lagrangian simulations

\begin{tabular}{llc}
\hline Parameters & Notation & Range \\
\hline Initial velocity $(\mathrm{m} / \mathrm{s})$ & $u_{0}$ & $100-400$ \\
Plume radius of vent $(\mathrm{m})$ & $l_{0}$ & $20-200$ \\
Gas mass fraction at vent & $n_{0}$ & $0.01-0.05$ \\
Plume temperature at vent $(\mathrm{K})$ & $\theta_{0}$ & $1100-1300$ \\
\hline
\end{tabular}

(Fig. 5). The $\mathrm{Md}_{\Phi}$ clearly reaches a similar maximum (around -2.5 ) at the dispersal axis and shows similar values away from it (Fig. 5a). Conversely, ash content is lowest for both layers at the dispersal axis (down to about $20 \mathrm{wt} . \%$ ) and increases away from it (up to $60 \mathrm{wt}$ \%) (Fig. 5c). Sorting does not show a clear pattern even along the crosswind direction (Fig. 5d).

The decrease of both $\mathrm{Md}_{\Phi}$ values and deposit thickness in the crosswind direction can be well described by a Gaussian fit (Fig. 5a, b). However, layer 3 is significantly thicker at any given distance from the dispersal axis (Fig. 5b).

\section{Total grain-size distributions and representative-sampling distance}

TGSDs calculated applying the Voronoi tessellation method of Bonadonna and Houghton (2005) for both layers are shown in Fig. 6. Several sample distributions and zero lines, i.e., lines of zero tephra load (Fig. 2), were considered in order to assess the sensitivity of the technique for these deposits. Layers 3 and 5 show very similar unimodal TGSD $\left(\mathrm{Md}_{\Phi}\right.$ is about -2.3 to $-2.1 \Phi$ and sorting is about 1.7 and $1.8 \Phi$ ). Tables 3 and 4 show how the TGSD derived based on only downwind samples does not diverge significantly from the TGSD derived based on the whole deposit (i.e., discrepancies are $\leq 5 \%$ for both layers). The shifting of the position of the zero line also does not affect the final TGSD (Tables 5 and 6). Regardless of the consistency of the results obtained for both layers, the associated TGSDs are likely to be fine depleted due to the limited deposit exposure.

In order to assess the TGSD completeness, simple Lagrangian simulations were performed (see "Methods" for the details of the methodology). In order to expand our results, we also explored particle transport associated with two other Plinian eruptions: Askja 1875 D and Pululagua 2450 BP (Fig. 7) (Sparks et al. 1981; Volentik et al. 2010). Eruptive parameters of all eruptions are shown in Table 7. Figure 7 shows how particles are advected below the tropopause height for Askja $1875 \mathrm{D}$ and Cotopaxi layers 3 and 5, while particles fall vertically below the cloud base for Pululagua 2450 BP due to the absence of wind. Because of the higher tropopause height, $3 \Phi$ particles travel farther for Cotopaxi layer 3 than for Askja $1875 \mathrm{D}$ even though plume height and wind velocity are similar (Table 5). Required sampling distances, i.e., the
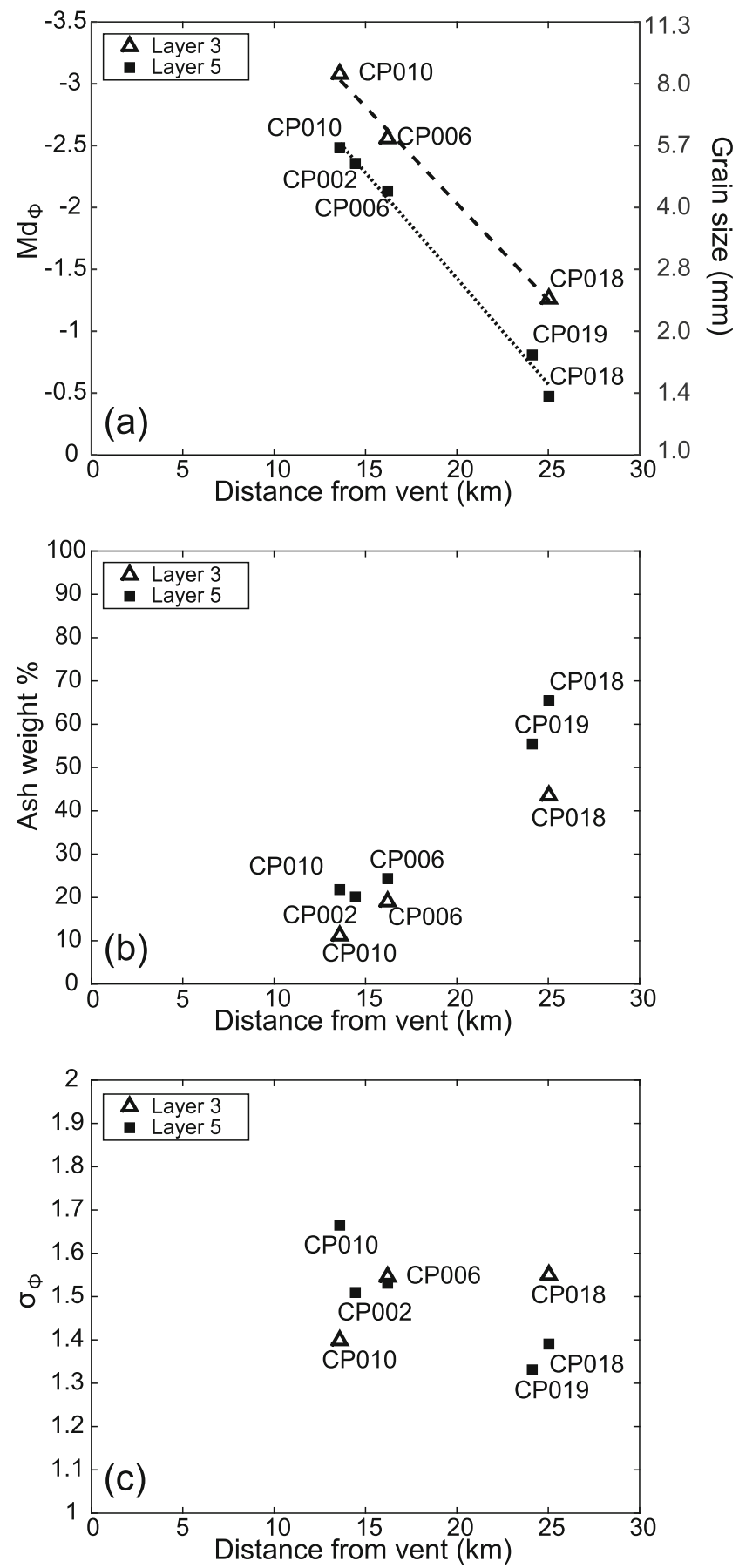

Fig. 4 Comparison of a median grain size $\left(\mathrm{Md}_{\Phi}\right)$, b weight percent of ash (i.e., particles $<2 \mathrm{~mm} / \geq 0 \Phi$ ), and $\mathbf{c}$ sorting along downwind axis for both layers 3 and 5. Numbers in box of (b) indicate the average and standard deviation of $\sigma_{\Phi}$ for each layer. Best-fit equations in Fig. 4a are $\mathrm{Md}_{\Phi}=0.16 D-5.1$ for layer $3(D$ distance in $\mathrm{km})$ and $\mathrm{Md}_{\Phi}=0.17 D-4.8$ for layer 5. Sorting average values of (c) are $1.5 \pm 0.1$ for layer 3 and $1.5 \pm 0.1$ for layer 5

distance to which tephra deposits should be sampled in order to derive a representative TGSD are, according to our Lagrangian simulations, 350, 380, 310, and $120 \mathrm{~km}$ for Askja D, Cotopaxi layer 3, Cotopaxi layer 5, and Pululagua deposits, 
Fig. 5 Comparison of a median grain size $\left(\mathrm{Md}_{\Phi}\right)$, b deposit thickness, $\mathbf{c}$ weight percent of ash (i.e., particles $>0 \Phi$ ), and $\mathbf{d}$ sorting $\left(\sigma_{\Phi}\right)$ for layers 3 and 5 along a crosswind section at a similar distance from the vent. Crosswind section of layer 3 is $15.7 \mathrm{~km}$ from the vent (CW1 of Fig. 2a). Crosswind section of layer 5 is $14.7 \mathrm{~km}$ (CW3 of Fig. 2b). Numbers in box of (b) indicate the average of $\sigma_{\Phi}$ standard deviation for each sorting average values of figure (d) are $1.6 \pm 0.1$ for layer 3 and $1.5 \pm 0.1$ for layer 5
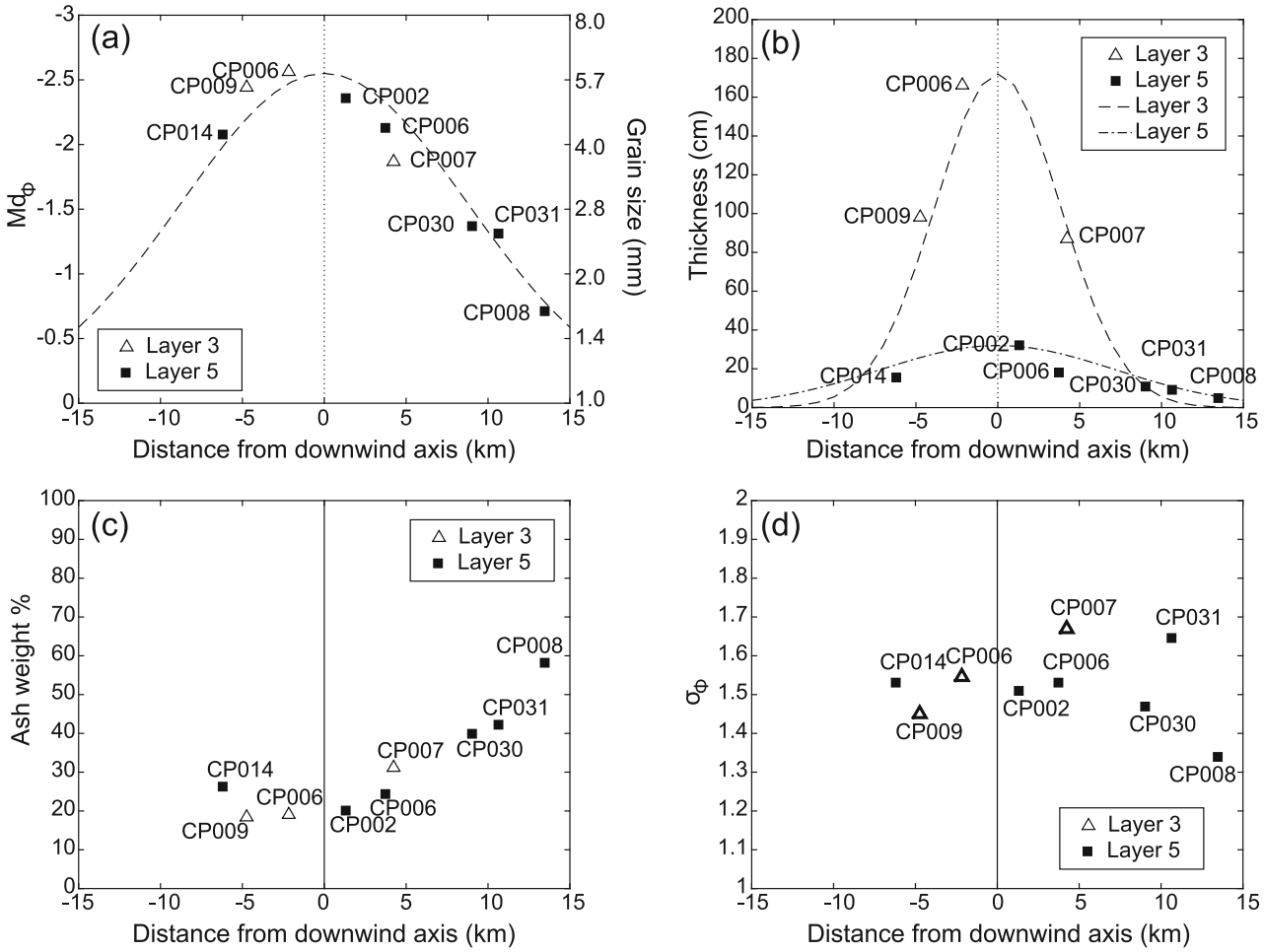

respectively (Fig. 7). The representative-sampling distance is determined based on the deposition distance of a $3-\Phi$ particle assuming that particles smaller than $62.5 \mu \mathrm{m}(4 \Phi)$ mostly sediment as aggregates (Brown et al. 2012) and should be considered as an approximation; caveats associated with this determination are discussed in the following section. Nonetheless, considering that the most distal outcrop was sampled at a distance of around $150 \mathrm{~km}$ for Askja $\mathrm{D}$ and $30 \mathrm{~km}$ for both layers of Cotopaxi and for Pululagua, all associated fieldderived TGSDs are likely to be fines depleted (see Fig. 6 and the Appendix for associated TGSDs).

In order to generalize the results for particle transport associated with a large eruption in varying wind conditions, Lagrangian simulations were also performed for the general case of a plume height of $30 \mathrm{~km}$ and maximum wind speed at the tropopause height of 10, 20, and $25 \mathrm{~m} / \mathrm{s}$ (Fig. 8). For different tropopause heights, Fig. 9 shows how representative-sampling distances are smaller for lower tropopause heights. The higher the tropopause height, the farther particles travel.

\section{Discussion}

This study provides interesting insights into the compilation of TGSDs, with a special focus on TGSDs associated with poorly exposed tephra deposits, such as those of Cotopaxi layers 3 and 5. As an example, we note that the samples along the downwind axes retain most of the grain-size information for both layers. This is probably due to the poor deposit exposure, which is limited for both layers, mostly because of vegetation cover or removal by erosion. Based on a sensitivity analysis of a better-exposed deposit, Bonadonna et al. (2015) show that crosswind data can be crucial to the TGSD determination. Nonetheless, the small sensitivity of the method to the position of the zero line is in agreement with the results of Volentik et al. (2010) and Bonadonna et al. (2015).

Some conclusions on plume and cloud dynamics could also be drawn. First, given that variations of grain-size distribution with distance from vent are mostly related to both plume height and wind advection (e.g., Carey and Sparks 1986), both downwind and crosswind variations of $\mathrm{Md}_{\Phi}$ values of Cotopaxi layers 3 and 5 imply similar plume heights. Second, the rate of grain-size decrease along the dispersal axis (Fig. 4a) and the grain-size variation along the crosswind direction show similar trends (Fig. 5a). This can be explained as the effects of umbrella cloud being similar for both eruptions. As discussed by Wilson and Walker (1987), especially in the crosswind directions, grain-size variations are mostly related to spreading of the umbrella cloud. Finally, $\mathrm{Md}_{\Phi}$ and thickness trends of both layers 3 and 5 are well described by a Gaussian fit (Fig. 5a, b) suggesting that particles are probably transported within a spreading turbulent current. The larger thickness of layer 3 is simply related to the larger erupted mass (Fig. 5b). In addition, the sorting shows no systematic trend even in the crosswind direction, indicating good mixing within the umbrella cloud. The crosswind increase of ash content away from the dispersal axis might indicate a preferential accumulation of fine particles on the sides of the umbrella cloud (Fig. 5c). 

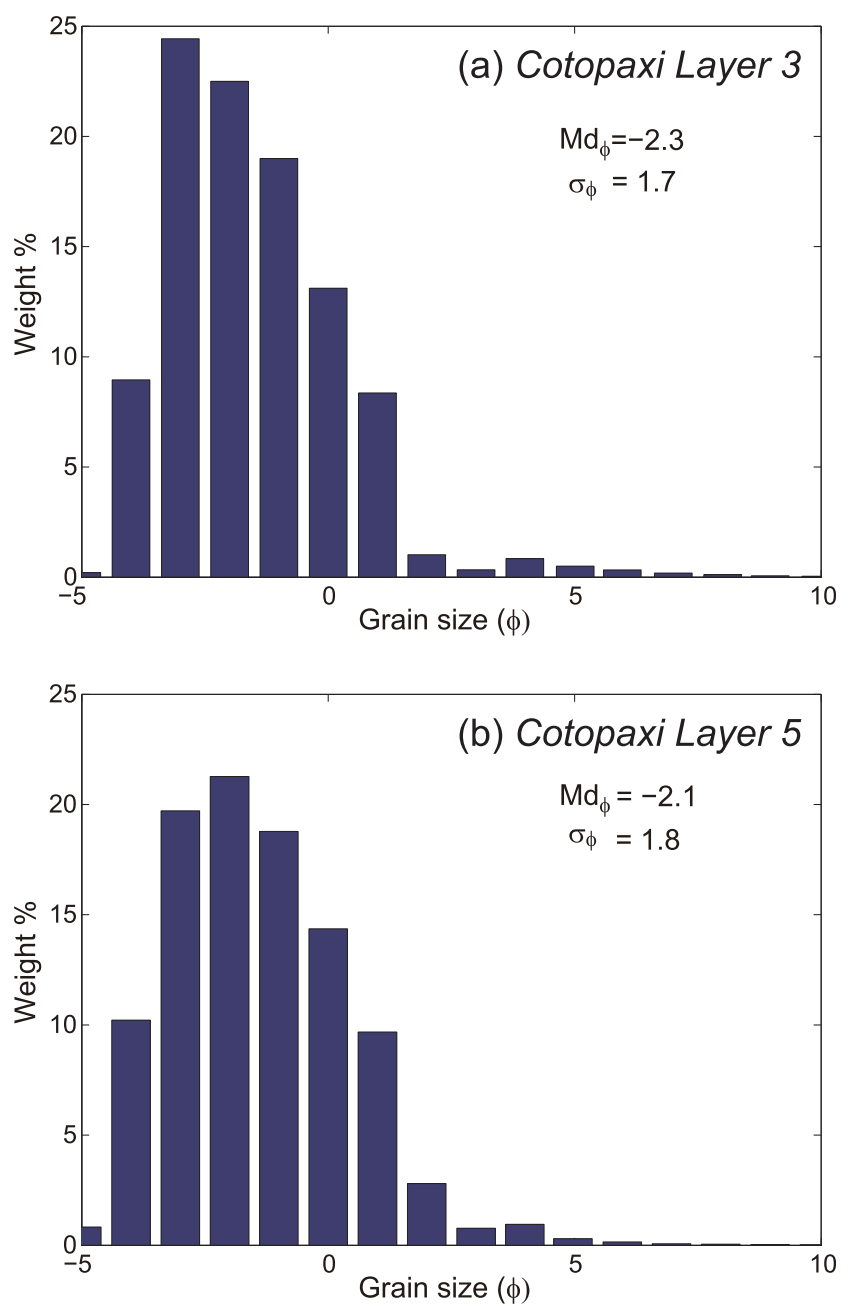

Fig. 6 TGSD of Cotopaxi a layers 3 and b 5

Finally, information about the representativeness of a TGSD can be derived. One crucial point in the characterization of explosive eruptions is how closely a TGSD derived from tephra deposits represents the initial grainsize distribution. Our Lagrangian simulations have shown that all the published TGSDs considered in this study (i.e., for Cotopaxi, Askja, and Pululagua) are probably fines depleted because deposit exposure on land is limited in extent, leading to distance-limited sampling. This is expected to be true for most published TGSDs, particularly those associated with prehistorical eruptions or with eruptions that occurred close to the ocean. In contrast, TGSDs derived for recent eruptions, for which the deposit was sampled during and/or soon after emplacement, are more likely to be complete. This is the case for the smallvolume Ruapehu 1996 deposit, which was sampled out to $150 \mathrm{~km}$ from vent just after the eruption (Bonadonna and Houghton 2005). Completeness of TGSD is indicated by the fact that the associated thinning trend can be described by at least three exponential segments on a semi-log plot of thickness versus distance from vent, while for our four case studies, it can be mostly described using only one exponential segment; only Askja 1875 D shows a proximal break-in slope (see also the discussion in Bonadonna and Houghton 2005 related to the completeness of thinning trends of tephra deposits). In any case, it is important to notice how all current methods for the determination of TGSD, ranging from simple data averaging to Voronoi tessellation, cannot account for missing data, and therefore they can only provide finedepleted TGSDs in the absence of distal deposits. Figure 8 shows simplified representative-sampling distances associated with a $30-\mathrm{km}$-high plume and different wind velocity (maximum wind speed at tropopause, 10, 20, and $25 \mathrm{~m} / \mathrm{s}$ ). Simulations also show how the tropopause height affects wind advection and particle travel distances (Figs 8 and 9). For example, the tropopause associated with Cotopaxi eruptions is higher (16 km a. s. 1.), because the volcano lies at low latitude, than is the tropopause associated with Askja eruptions (9 km a. s. 1.). Given that wind speed typically decreases linearly above the tropopause, particles associated with the Cotopaxi layer 3 eruption traveled farther than particles associated with the Askja 1875 D eruption, even though their plume height

Table $3 \operatorname{Md}_{\Phi}$ and $\sigma_{\Phi}$ of total grain-size distribution for layer 3

\begin{tabular}{llcccc}
\hline & All points $^{\mathrm{a}}$ & DW & DW+CW1 & DW+CW2 & DW+CW1+CW2 \\
\hline Number of points & 14 & 3 & 6 & 8 & 11 \\
Md $_{\Phi}$ & -2.3 & -2.3 & -2.2 & -2.2 & -2.2 \\
$\sigma_{\Phi}$ & 1.7 & 1.7 & 1.7 & 1.7 & 1.7 \\
Error $^{\mathrm{b}}(\%)$ & - & 0.0 & 4.3 & 4.3 & 4.3 \\
\hline
\end{tabular}

$D W$ total grain size calculated considering only samples along the downwind axis, $D W+C W 1$ total grain size calculated from the points along the downwind axis and crosswind section 1 (15.7 km from the vent), $D W+C W 2$ indicate the total grain size calculated from the points along the downwind axis and crosswind section 2 (18.0 km from the vent), $D W+C W 1+C W 2$ total grain size calculated from the samples along the downwind axis, crosswind section 1 , and crosswind section 2

${ }^{\mathrm{a}}$ The TGSD calculated from all points sampled for layer 3 (all points in Fig. 2a except the empty circles)

${ }^{\mathrm{b}}$ The percentage of difference of $\mathrm{Md}_{\Phi}$ from all points 
Table $4 \quad \mathrm{Md}_{\Phi}$ and $\sigma_{\Phi}$ of TGSD for layer 5

\begin{tabular}{llcccccc}
\hline & All points $^{\mathrm{a}}$ & DW & DW+CW1 & DW+CW2 & DW+CW3 & DW+CW2+CW3 & DW+CW1+CW2+CW3 \\
\hline Number of points & 24 & 5 & 8 & 9 & 11 & 15 & 16 \\
Md $_{\Phi}$ & -2.1 & -2.2 & -2.0 & -2.3 & -1.9 & -2.2 & -2.1 \\
$\sigma_{\Phi}$ & 1.8 & 1.7 & 1.8 & 1.7 & 1.6 & 1.7 & 1.8 \\
Error $^{\mathrm{b}}(\%)$ & - & 4.8 & 4.8 & 9.5 & 9.5 & 4.8 & 0.0 \\
\hline
\end{tabular}

$D W$ TGSD calculated only samples along the downwind axis, $D W+C W 1$ TGSD calculated from the samples along the downwind axis and along the crosswind section $1(0.0 \mathrm{~km}$ from the vent), $D W+C W 2$ TGSD calculated from the samples along the downwind axis and along the crosswind section 2 (7.3 km from the vent), $D W+C W 3$ TGSD calculated from the samples along the downwind axis and along the crosswind section 3 (14.7 km from the vent), $D W+C W 1+C W 2$ TGSD calculated from the samples along the downwind axis and along crosswind sections 1 and $2, D W+C W 1+C W 2+C W 3$ TGSD calculated from the samples along the downwind axis and all cross wind sections

${ }^{\mathrm{a}}$ The TGSD calculated from all points sampled for layer 5 (all points in Fig. $2 \mathrm{~b}$ except the empty circles)

${ }^{\mathrm{b}}$ The percentage of difference of $\mathrm{Md}_{\Phi}$ from all points

and maximum wind velocity is similar (Table 7). As a result, representative-sampling distances for a given plume height and wind velocity are smaller for eruptions occurring at higher altitudes for which the tropopause height is lower (Fig. 9). It is important to note that, considering the simplicity of our Lagrangian simulations, the representative-sampling distances derived in this study are only an indication and some caveats are here discussed. First, the wind field in our simulations was kept constant for simplicity, but it typically varies with distance from vent with the potential of affecting the final representative-sampling distance. Second, particle shape was considered spherical, and our simulations might overestimate particle settling velocity predicting smaller representativesampling distances than expected for irregular particles. Third, our representative-sampling distances are derived based on particle size only and not on deposit thickness; it is clear that the thicker the deposit at individual outcrops the larger weight will have on the determination of

Table 5 Differences in $\mathrm{Md}_{\Phi}$ and $\sigma_{\Phi}$ of TGSD for layer 3 related to different zero-mass lines considered for the Voronoi Tessellation technique

\begin{tabular}{llll}
\hline & Zero line $1^{\mathrm{a}}$ & ${\text { Zero line } 2^{\mathrm{b}}}$ & Zero line $3^{\mathrm{c}}$ \\
\hline $\mathrm{Md}_{\Phi}$ & -2.3 & -2.3 & -2.4 \\
$\sigma_{\Phi}$ & 1.7 & 1.7 & 1.7 \\
Error $^{\mathrm{d}}(\%)$ & - & 0 & 4.3 \\
\hline
\end{tabular}

a The line of zero thickness of layer 3 shown in the isopach map of Fig. 2 (dashed line)

${ }^{\mathrm{b}}$ The lines traced $5 \mathrm{~km}$ further out from zero line 1

${ }^{\mathrm{c}}$ The lines traced $10 \mathrm{~km}$ further out from zero line 1

${ }^{\mathrm{d}}$ The percentage of difference of $\mathrm{Md}_{\Phi}$ from zero line 1
TGSD. As a result, very distal thin deposits might not have a large influence on the final calculations. Fourth, particle aggregation, which was not considered in this study, enhances fine-ash sedimentation in proximal to medial areas. As a result, the representative-sampling distances would be reduced for eruptions characterized by size-selective sedimentation processes (e.g., particle aggregation, convective instabilities). Finally, a $3-\Phi$ size threshold (i.e., $125 \mu \mathrm{m}$ ) was selected for simplicity to describe the trajectory of the finest particles that do not aggregate. It has been shown that particles $<125 \mu \mathrm{m}$ are preferentially incorporated into aggregates (Schumacher 1994 and Van Eaton et al. 2012). However, aggregates that also include larger particles, or that only contain smaller particles, have also been observed (Brown et al. 2012). More studies on particle aggregation are required to assess the uncertainty of such a size threshold and to evaluate the variation of the resulting representativesampling distance.

Table 6 Differences in $\operatorname{Md}_{\Phi}$ and $\sigma_{\Phi}$ of TGSD for layer 5 related to different zero-mass lines considered for the Voronoi Tessellation technique

\begin{tabular}{llcc}
\hline & Zero line $1^{\mathrm{a}}$ & ${\text { Zero line } 2^{\mathrm{b}}}$ & Zero line $3^{\mathrm{c}}$ \\
\hline $\mathrm{Md}_{\Phi}$ & -2.1 & -2.0 & -2.0 \\
$\sigma_{\Phi}$ & 1.8 & 1.9 & 1.9 \\
Error $^{\mathrm{d}}(\%)$ & - & 4.8 & 4.8 \\
\hline
\end{tabular}

${ }^{\mathrm{a}}$ The line of zero thickness of layer 3 shown in the isopach map of Fig. 2 (dashed line)

${ }^{\mathrm{b}}$ The lines traced $5 \mathrm{~km}$ further out from zero line 1

${ }^{\mathrm{c}}$ The lines traced $10 \mathrm{~km}$ further out from zero line 1

${ }^{\mathrm{d}}$ The percentage of difference of $\mathrm{Md}_{\Phi}$ from zero line 1 
Fig. 7 Particle trajectories calculated with a simple Lagrangian method for a Askja 1875D, b Cotopaxi layer 3, c Cotopaxi layer 5, and $\mathbf{d}$ Pululagua 2450BP eruptions. Legends show the grain size in $\Phi$. Horizontal solid line shows the total plume height $\left(H_{t}\right)$. Horizontal dasheddotted line shows the neutral buoyancy height of the plume $\left(H_{b}\right)$. Horizontal dashed line shows the tropopause height. Sampling distances are shown with arrows for each eruption (a) Askja 1875D

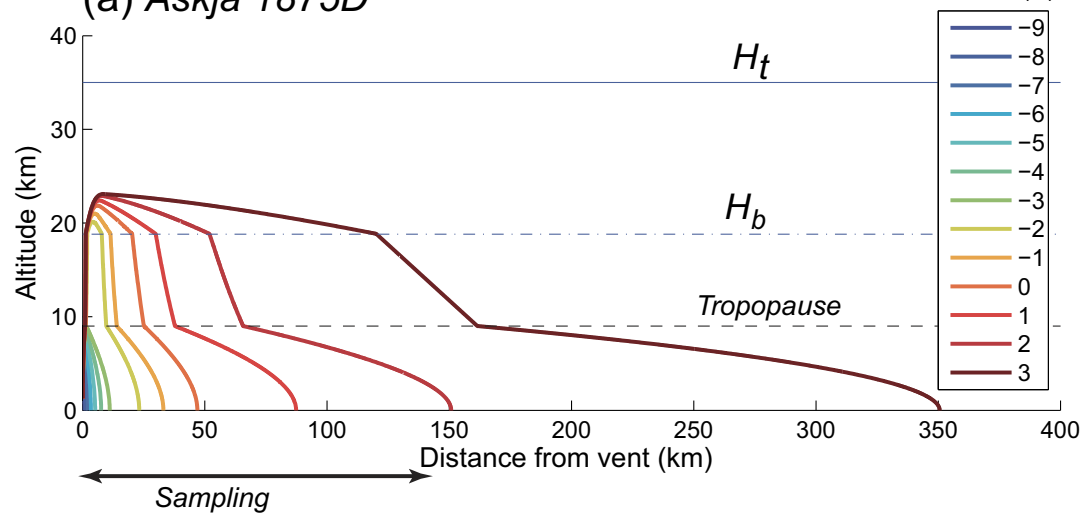

(b)Cotopaxi Layer 3

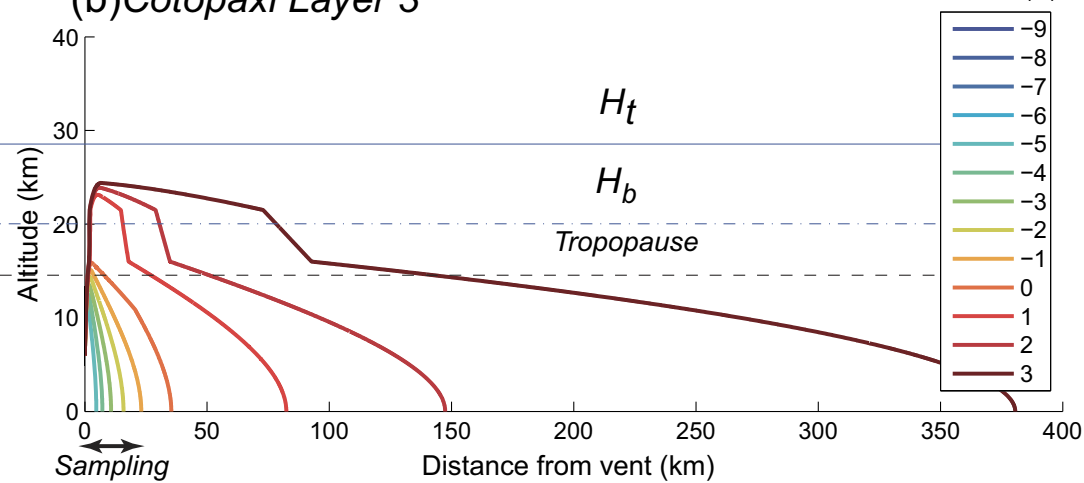

(c)Cotopaxi Layer 5

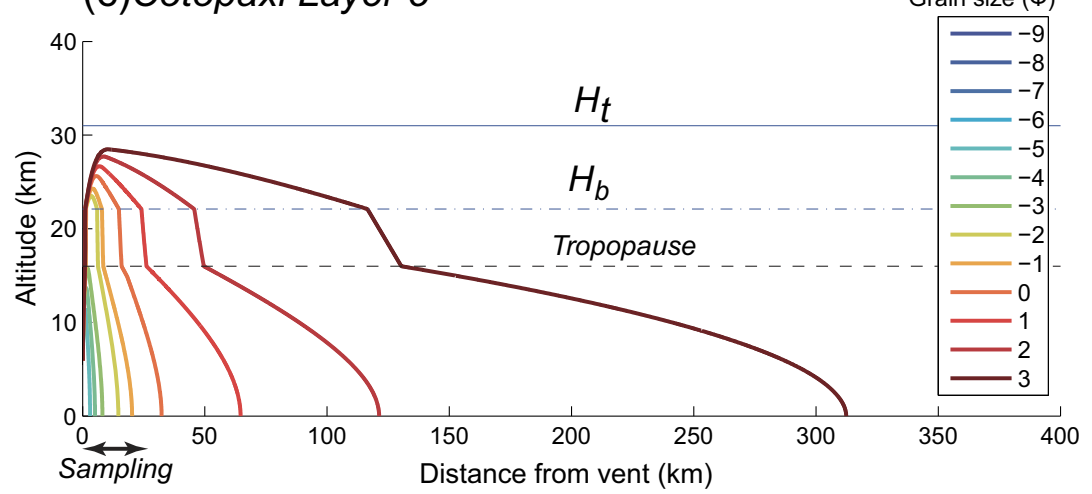

(d)Pululagua 2450BP

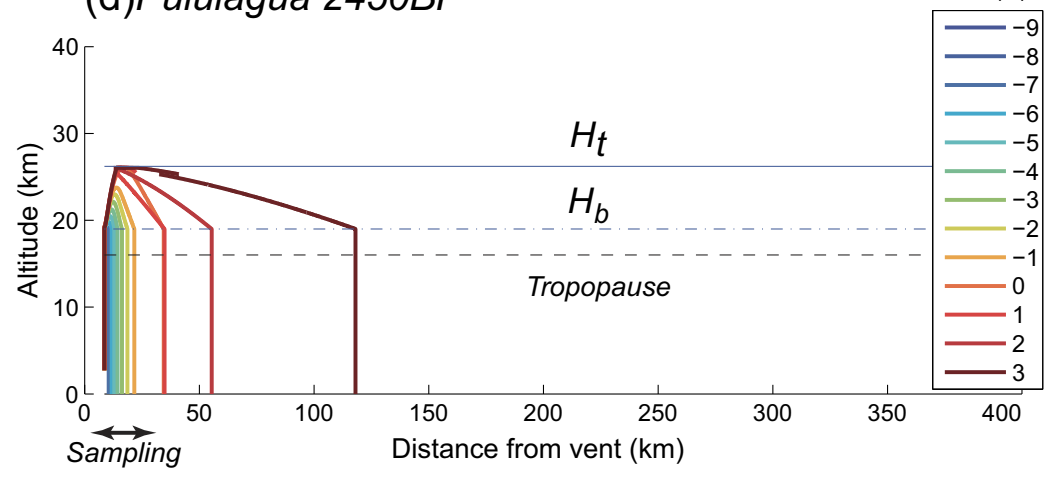


Table 7 Eruption parameters and TGSD parameters for selected eruptions of Askja, Cotopaxi, and Pululagua volcanoes

\begin{tabular}{|c|c|c|c|c|c|c|c|c|}
\hline \multirow[t]{2}{*}{ Eruption } & \multirow{2}{*}{$\begin{array}{l}\text { Plume height above } \\
\text { vent }(\mathrm{km})\end{array}$} & \multirow{2}{*}{$\begin{array}{l}\text { Wind speed at } \\
\text { tropopause }(\mathrm{m} / \mathrm{s})\end{array}$} & \multirow[t]{2}{*}{ Eruption style } & \multirow{2}{*}{$\begin{array}{l}\text { Erupted mass } \\
(\mathrm{kg})\end{array}$} & \multirow[t]{2}{*}{$\operatorname{MER}(\mathrm{kg} / \mathrm{s})$} & \multirow[t]{2}{*}{ Duration (h) } & \multicolumn{2}{|c|}{ TGSD } \\
\hline & & & & & & & $\mathrm{Md}_{\Phi}$ & $\sigma_{\Phi}$ \\
\hline Askja $1875 \mathrm{D}$ & 26 & 28 & Plinian & $5.0 \times 10^{11}$ & $2.5 \times 10^{7}$ & 6.0 & -2.3 & 4.2 \\
\hline Cotopaxi layer 3 & 23 & 28 & Plinian & $1.7 \times 10^{12}$ & $4.9 \times 10^{7}$ & $2.3-12.7$ & -2.3 & 1.7 \\
\hline Cotopaxi layer 5 & 26 & 21 & Plinian & $0.6 \times 10^{12}$ & $5.0 \times 10^{7}$ & $1.0-1.8$ & -2.1 & 1.8 \\
\hline Pululagua 2450 BР & 24.5 & 0 & Plinian (no wind) & $3.0-5.0 \times 10^{11}$ & $6.2-18.0 \times 10^{7}$ & $0.8-3.0$ & 0.2 & 1.9 \\
\hline
\end{tabular}

Askja D 1875: Carey et al. (2010), Carey and Sparks (1986), and Sparks et al. (1981). Cotopaxi layers 3 and 5: Biass and Bonadonna (2011). Pululagua: Volentik et al. (2010)

Fig. 8 Particle trajectories calculated with a simple Lagrangian method for an eruption occurring at low latitudes and characterized by a plume height of $30 \mathrm{~km}$ and various wind speed: a 10 , b 20 , and c $25 \mathrm{~m} / \mathrm{s}$. Symbols are in Fig. 7
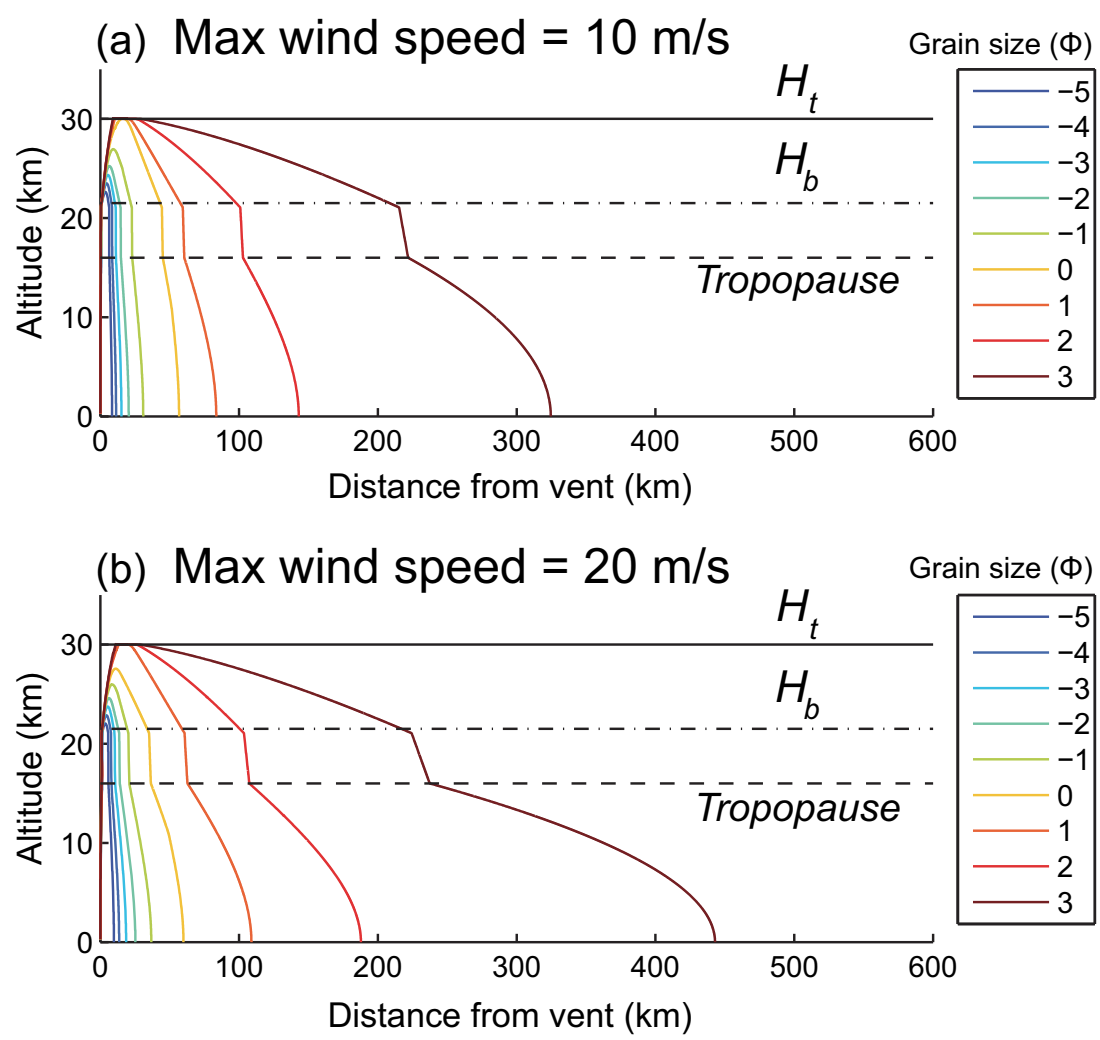

(c) Max wind speed $=25 \mathrm{~m} / \mathrm{s}$

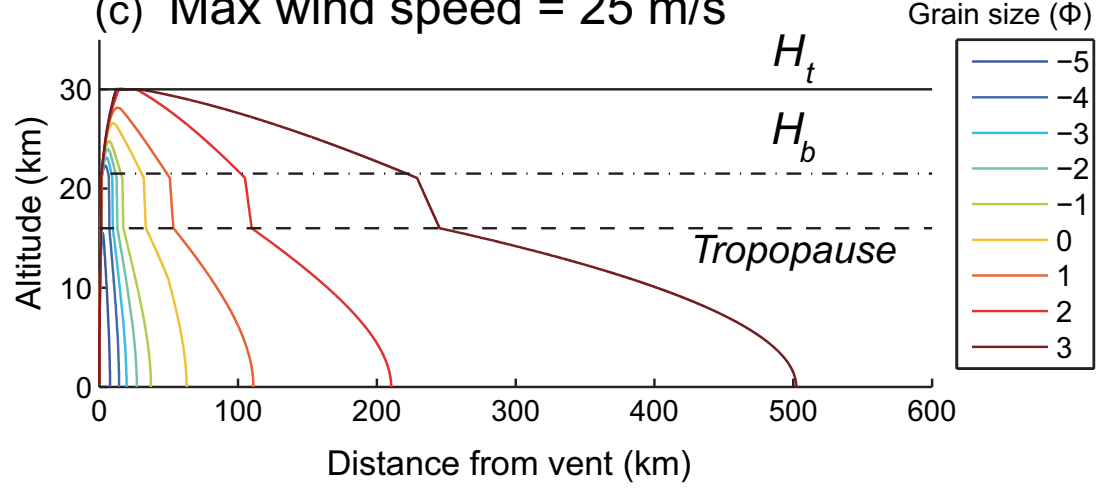




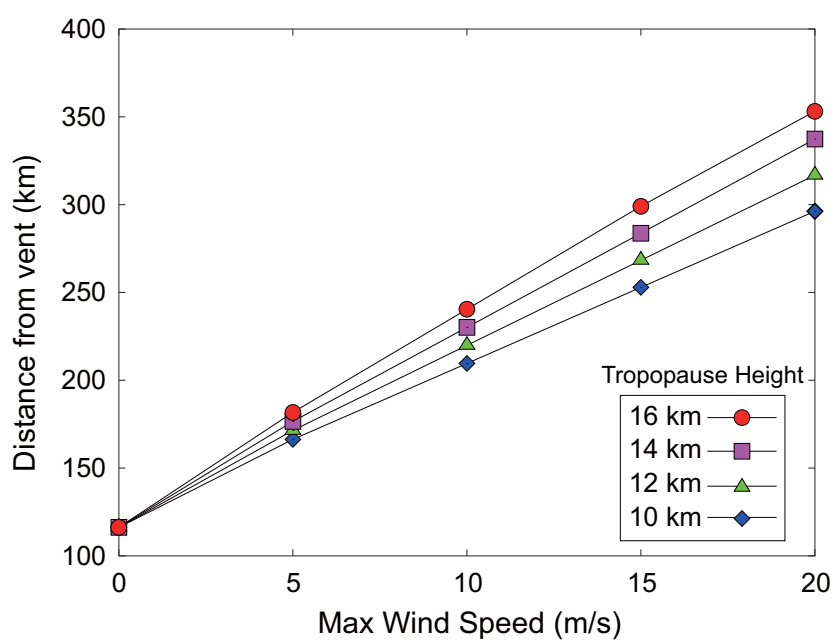

Fig. 9 Plot showing the dependence of the representative-sampling distance (of $125 \mu \mathrm{m}$ particles) on both the wind speed and the height of the tropopause based on our Lagrangian simulations. Plume height $\left(H_{t}\right)$ is $30 \mathrm{~km}$. Tropopause heights of $10,12,14$, and $16 \mathrm{~km}$ correspond to the latitude of $58,44,33,20$ degrees respectively

\section{Conclusions}

By combining field data for two large Cotopaxi plinian eruptions (layers 3 and 5) with dedicated numerical simulations, we provide new insights into grain-size features of tephra deposits:

1. Cotopaxi layer 3 and 5 eruptions are characterized by similar plume height (23 and $26 \mathrm{~km}$ above the vent), similar $\operatorname{Md}_{\Phi}$ and $\sigma_{\Phi}(-2.3,-2.1,1.7$, and 1.8, respectively), but different erupted masses $\left(1.7 \times 10^{12}\right.$ and $0.6 \times 10^{12} \mathrm{~kg}$, respectively) and wind advection ( 28 and $21 \mathrm{~m} / \mathrm{s}$ at tropopause, respectively). As a result, variations of grain-size features $\left(\mathrm{Md}_{\Phi}\right.$ and ash content) with distance from vent (controlled by both plume height and wind advection) are more pronounced in the downwind direction than in the crosswind direction (mainly controlled by plume height).

2. $\operatorname{Md}_{\Phi}$ and deposit thickness of Cotopaxi layer 3 and 5 eruptions decrease along crosswind axis in a Gaussian fashion, but while grain-size is similar for both layers at any given distance from vent, layer 3 is always thicker than layer 5 probably due to a larger erupted mass.

3. TGSDs derived using existing averaging techniques are likely to be fines depleted if the deposit is not sampled down to the representative-sampling distance, which is mostly a function of plume height, wind speed and tropopause height. As an example, to be TGSD representative, samples must be taken out to a distance of around $350 \mathrm{~km}$ from the vent for the deposits associated with Askja 1875 $\mathrm{D}$ and for both Cotopaxi layers 3 and 5. Samples to a distance of only around $120 \mathrm{~km}$ are required for Pululagua 2450 BP because there was no wind advection.

4. Simplified representative-sampling distances, for an eruption happening at a similar latitude as Cotopaxi volcano (with a tropopause height of $16 \mathrm{~km}$ a.s.l) and characterized by a plume height of $30 \mathrm{~km}$, with maximum wind speeds of 10 and $20 \mathrm{~m} / \mathrm{s}$, are about 250 and $350 \mathrm{~km}$, respectively. Representative-sampling distances for eruptions with similar plume height but occurring at higher latitudes (with a tropopause height $10 \mathrm{~km}$ a.s.l) are smaller (e.g., about 200 and $300 \mathrm{~km}$ for wind speeds of 10 and $20 \mathrm{~m} / \mathrm{s}$, respectively).

5. Other important parameters and processes, which are not discussed in this paper but that might also play an important role, include particle aggregation (with implications for the smallest grain sizes considered in the simulations), settling velocities of irregular particles, and mass distribution in a deposit.

Acknowledgments This project was supported by the Swiss National Science Foundation (No. 200021-116335). We thank Raffaello Cioni, Marco Pistolesi, Sebastien Biass, Licia Costantini, and Mauro Rosi for the support during our field work in Cotopaxi and Sebastien Biass also for his support during the writing phase of this manuscript. We appreciate three reviewers for their helpful comments and advices.

\section{Appendix}

(a)

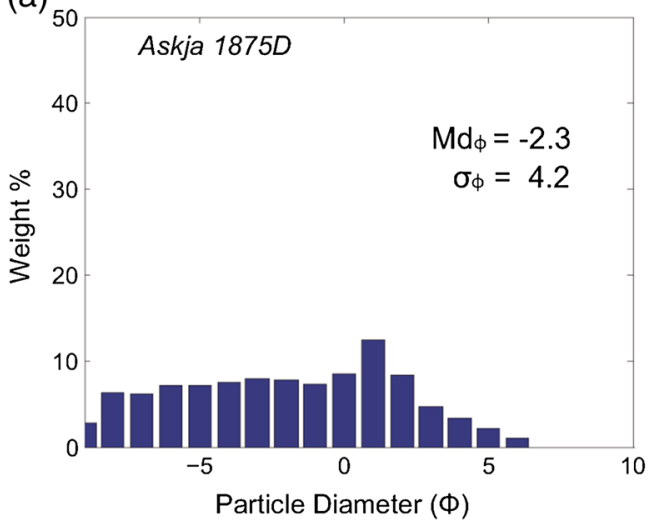

(b)

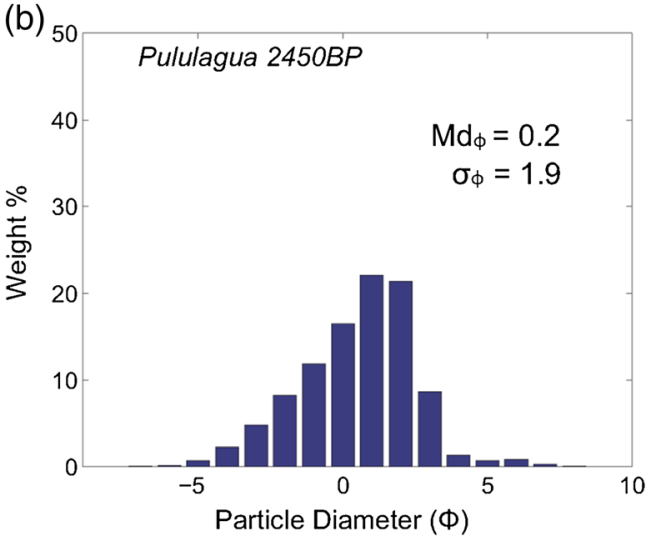

Fig. 10 Field-derived TGSDs of Askja 1875D and Pululagua 2450BP eruptions (from Sparks et al. 1981; Volentik et al. 2010, respectively) 


\section{References}

Barberi F, Coltelli M, Frullani A, Rosi M, Almeida E (1995) Chronology and dispersal characteristics of recently (last 5000 years) erupted tephra of Cotopaxi (Ecuador): implications for long-term eruptive forecasting. J Volcanol Geotherm Res 69(3- 4):217-239

Biass S, Bonadonna C (2011) A quantitative uncertainty assessment of eruptive parameters derived from tephra deposits: the example of two large eruptions of Cotopaxi volcano, Ecuador. Bull Volcanol 73: 73-90

Bonadonna C, Costa A (2013) Modeling of tephra sedimentation from volcanic plumes. In: Fagents SA, Gregg TKP, Lopes RMC (eds) Modeling volcanic processes: the physics and mathematics of volcanism. Cambridge University Press, CAMBRIDGE, pp 173-202. ISBN 9780521895439

Bonadonna C, Houghton BF (2005) Total grain-size distribution and volume of tephra-fall deposits. Bull Volcanol 67:441-456

Bonadonna C, Phillips JC (2003) Sedimentation from strong volcanic plumes. J Geophys Res 108(B7):2340-2368

Bonadonna C, Biass S, Costa A (2015) Physical characterization of explosive volcanic eruptions based on tephra deposits: propagation of uncertainties and sensitivity analysis. J Volcanol Geothermal Res 296:80-100

Brown R, Bonadonna C, Durant A (2012) A review of volcanic ash aggregation. Phys Chem Earth 45-46:65-78

Bursik MI, Sparks RSJ, Gilbert JS, Carey SN (1992) Sedimentation of tephra by volcanic plumes: I. Theory and its comparison with a study of the Fogo A plinian deposit, Sao Miguel (Azores). Bull Volcanol 54:329-344

Carey SN, Sigurdsson H (1982) Influence of particle aggregation on deposition of distal tephra from the May 18, 1980, eruption of Mount St. Helens volcano. J Geophys Res 87(B8):7061-7072

Carey S, Sparks RSJ (1986) Quantitative models of the fallout and dispersal of tephra from volcanic eruption columns. Bull Volcanol 48: $109-125$

Carey RJ, Houghton BF, Thordarson T (2010) Tephra dispersal and eruption dynamics of wet and dry phases of the 1875 eruption of Askja volcano, Iceland. Bull Volcanol 72:259-278

Connor LJ, Connor CB (2006) Inversion is the key to dispersion understanding eruption dynamics by inverting tephra fallout. In: Mader HM, Connor CB, Coles SG, Connor LJ (eds) Statistics in volcanology special publications of IAVCEI, 1. Geological Society, London, pp 231-242

Costantini L (2010) Understanding basaltic explosive volcanism. PhD dissertation, Université de Genève, Switzerland

Eychenne J, Le Pennec J-L, Troncoso L, Gouhier M, Nedelec J-M (2012) Causes and consequences of bimodal grain-size distribution of tephra fall deposited during the August 2006 Tungurahua eruption (Ecuador). Bull Volcanol 74(1):187-205

Fierstein J, Nathanson M (1992) Another look at the calculation of fallout tephra volumes. Bull Volcanol 54(2):156-167

Folch A (2012) A review of tephra transport and dispersal models: evolution, current status, and future perspectives. J Volcanol Geotherm Res 235-236(1):96-115

Inman DL (1952) Measures for describing the size distribution of sediments. J Sediment Petrol 22:125-145
Kaminski E, Jaupart C (1998) The size distribution of pyroclasts and the fragmentation sequence in explosive volcanic eruptions. J Geophys Res 103(B12):29759-29779

Koyaguchi T, Ohno M (2001a) Reconstruction of eruption column dynamics on the basis of grain-size of tephra-fall deposits: part 1 . Methods. J Geophys Res 106:6499-6512

Koyaguchi T, Ohno M (2001b) Reconstruction of eruption column dynamics on the basis of grain-size of tephra-fall deposits: part 2 . Application to the Pinatubo 1991 eruptions. J Geophys Res 106: 6513-6533

Mastin LG, Guffanti M, Servranckx R, Webley P, Barsotti S, Dean K, Durant A, Ewert JW, Neri A, Rose WI, Schneider D, Siebert L, Stunder B, Swanson G, Tupper A, Volentik A, Waythomas CF (2009) A multidisciplinary effort to assign realistic source parameters to models of volcanic ash-cloud transport and dispersion during eruptions. J Volcanol Geotherm Res 186:10-21

Murrow PJ, Rose WI, Self S (1980) Determination of the total grain size distribution in a Vulcanian eruption column, and its implications to stratospheric aerosol perturbation. Geophys Res Lett 7:893-896

Newhall CG, Self S (1982) The volcanic explosivity index (VEI) an estimate of explosive magnitude for historical volcanism. J Geophys Res 87:1231-1238

Parfitt E (1998) A study of clast size distribution, ash deposition and fragmentation in a Hawaiian-style volcanic eruption. J Volcanol Geotherm Res 84:197-208

Pyle DM (1989) The thickness, volume and grainsize of tephra fall deposits. Bull Volcanol 51(1):1-15

Schumacher R (1994) A reappraisal of Mount St. Helens ash clusters depositional model from experimental-observation. J Volcanol Geotherm Res 59(3):253-260

Sparks RSJ (1986) The dimensions and dynamics of volcanic eruption columns. Bull Volcanol 48:3-15

Sparks RSJ, Wilson L, Sigurdsson H (1981) The pyroclastic deposits of the 1875 eruption of Askja, Iceland. Philos Trans R Soc Lond 299: 241-273

Van Eaton AR, Muirhead JD, Wilson CJN, Cimarelli C (2012) Growth of volcanic ash aggregates in the presence of liquid water and ice: an experimental approach. Bull Volcanol 74(9):1963-1984

Volentik ACM, Bonadonna C, Connor CB, Connor LJ, Rosi M (2010) Modeling tephra dispersal in absence of wind: insights from the climactic phase of the 2450 BP plinian eruption of Pululagua volcano (Ecuador). J Volcanol Geotherm Res 193(1-2):117-136

Walker GPL (1971) Grain-size characteristics of pyroclastic deposits. J Geol 79(6):696-714

Walker GPL (1980) The Taupo pumice: product of the most powerful known (ultraplinian) eruption? J Volcanol Geotherm Res 8:69-94

Walker GPL (1981a) Characteristics of two phreatoplinian ashes, and their water-flushed origin. J Volcanol Geotherm Res 9:395-407

Walker GPL (1981b) Plinian eruptions and their products. Bull Volcanol 44:223-240

Walker GPL (1981c) The Waimihia and Hatepe plinian deposits from the rhyolitic Taupo Volcanic Centre. N Z J Geol Geophys 24:305-324

Wilson L, Walker GPL (1987) Explosive volcanic eruptions-VI. Ejecta dispersal in Plinian eruptions: the control of eruption conditions and atmospheric properties. Geophys J R Astron Soc 89(2):657-679

Woods AW (1988) The fluid dynamics and thermodynamics of plinian eruption columns. Bull Volcanol 50:169-193 